\title{
Maurice Hilleman
}

Few youngsters might recognize Maurice Hilleman as the man behind their childhood immunizations. But with more than 40 vaccines to his credit, it's no exaggeration to say Hilleman saves millions of lives each year.

On 26 January, some of the world's most famous and accomplished biomedical researchers gathered in Philadelphia to honor Maurice Hilleman. That evening, Hilleman thanked the group, saying, "there's no greater tribute that anyone can pay to a scientist than to give approval to a peer. All of you I think of as peers in the world of science."

Addressed to a group of more than a hundred people, the statement was clearly absurd. By any objective measure, a gathering of Maurice Hilleman's scientific peers would not fill a telephone booth.

Hilleman has produced a mind-boggling number of fundamental breakthroughs. He is the inventor of more than 40 vaccines, including those that prevent measles, mumps, rubella, Haemophilus influenzae type b, hepatitis A, hepatitis B and chickenpox. Epidemiologists often refer to the first few decades after World War II as the golden age of vaccinology. It might be more accurate to call it the Hilleman period. According to one estimate, his vaccines save nearly 8 million lives a year.

Hilleman also discovered SV40 and the adenoviruses, was the first to purify interferon, and the first to demonstrate that its expression is induced by double-stranded RNA-discoveries that launched several branches of molecular biology and immunology and jump-started the quest for antiviral medications.

Astonishingly, despite transforming the nature of public health, he seems to be fading into obscurity.

"Very few people, even in the scientific community, are even remotely aware of the scope of what Maurice has contributed," Anthony Fauci, director of the US National Institutes of Allergy and Infectious Diseases, noted at the symposium. "I recently asked my post-docs whether they knew who had developed the measles, mumps, rubella, hepatitis B and chickenpox vaccines. They had no idea," Fauci said. "When I told them that it was Maurice Hilleman, they said, 'Oh, you mean that grumpy guy who comes to all of the AIDS meetings?"”

Indeed, Hilleman's reputation as a prickly character often overshadows his accomplishments. Even at 86 , he is a tall, confident man with a firm handshake who speaks softly but bluntly_and often profanely. Relating the story of how he met his wife, Lorraine, for example, he described his dating experiences in 1962: "I had a couple of dates. Christ. Finding women is sort of like by Brownian action. You don't know whether they're drunkards, or they'll spend all your money, or whether they have venereal diseases."

Giving up on the dating scene, he instead decided to hunt for a wife among the job applicant pool at Merck and Company in West Point, Pennsylvania, where he worked. He enlisted the aid of his administrative assistant. "I said, 'Look, Ken, I want you to go through all these [job] applications and pick out what looks good to you, then send them up to me, and we'll do that once a week until we find one," Hilleman recalls. On hearing this, a young woman in the audience at the symposium remarked to her companion, "You couldn't get away with that today."

The same could be said about much of Hilleman's career. "Unlike other people in research, Maurice did every aspect of research and development," notes P. Roy Vagelos, former chairman and chief executive officer of Merck. Hilleman characterized antigens and isolated them, then did the basic research, the process research and the clinical research, Vagelos says. Following clinical trials, Hilleman would also haunt the manufacturing facility to ensure that the vaccine was being produced correctly. "The manufacturing people were not quite used to that, so there was a constant grumble at that end of the campus," says Vagelos.

"I ran into conflict with just about everybody," Hilleman concedes. "I was told I had a very unusual management style. In spite of all this, I survived at Merck." Asked if his one-man pipeline approach could work today, "it takes somebody who's a bastard," Hilleman says. "I don't think there are basically any people at all left who would have the dedication."

A strong proponent of a seven-day work week for scientists, Hilleman cites his upbringing on a farm in rural Montana as the inspiration for both his work ethic and his coarse language. Though he officially retired on his 65th birthday in accordance with Merck's mandatory retirement policy, the company immediately re-hired him as a consultant, and he still goes to his office every day. During the course of a long interview one morning in February, he discussed everything from Sinclair Lewis's novel Arrowsmith to the latest research on HIV and tuberculosis, revealing himself to be a sharp and voracious reader.

His dedication to his work is superseded only by his devotion to his family. Asked about his pastimes, Hilleman says, "my hobby is working." There are dozens of stories about this workaholic virologist, but one of the most famous highlights his intense focus on public health. In 1963, when his oldest daughter, Jeryl Lynn, developed the characteristic fever and swollen glands of mumps, he made a late-night trip to the laboratory to retrieve some equipment, then returned home to culture her virus.

\section{"I ran into conflict with just about everybody... I was told I had a very unusual management style. In spite of all this, I survived at Merck."}

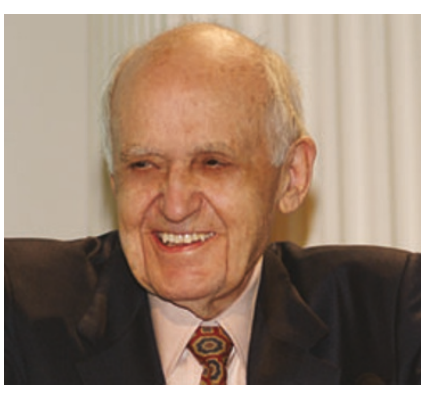

Jeryl recovered from the mumps virus, but the mumps virus never recovered from infecting Jeryl. Using the isolate from his daughter, Hilleman attenuated the virus and shepherded it through testing and production in his typical fashion. His younger daughter, Kirsten, participated in the early clinical trials. This now-standard mumps vaccine has since brought a classic childhood disease to the brink of extinction.

Looking at the current landscape of vaccinology, Hilleman advocates more collaboration between industry, academic and government researchers to develop the next generation of vaccines, a view that he says only recently became acceptable. "If you go back in history, industry was a leper," he says. When he finished his doctoral work at the University of Chicago, he adds, "I was told ... 'we do not train people for industry,' so I said what the hell, that's exactly where I'm going."

From Chicago, Hilleman went to E.R. Squibb and Sons in New Jersey in 1944, then to the Walter Reed Army Institute of Research in Washington in 1948, finally joining Merck in 1957. According to Adel Mahmoud, president of the Merck Vaccine Division, the company currently produces seven vaccines, all invented by Maurice Hilleman. "This guy, whatever he touched, he developed a vaccine out of it," says Mahmoud. "We owe him an incredible, incredible debt."

Alan Dove, Philadelphia 